\title{
Whistle-blown into nothingness: The Boeing Story
}

\author{
Chux Gervase Iwu \\ Faculty of Business, Cape Peninsula University of Technology \\ chuxiwu@gmail.com
}

\section{Case Overview}

Julian Assange of Wikileaks has become a cult figure. Not much was known about this founder of a whistle blowing web site until recently when he published what most governments around the world would not have us, ordinary people, read. On South Africa's Reconciliation Day, 16 December 2010, Al Jazeera, an international news channel, blew a second whistle on Boeing. I call this a 'second whistle' because two former employees (let us call them Mr and Mrs Jones) of Boeing had earlier blown a whistle that warned the American government against substandard manufacturing and procurement processes employed by Boeing. These whistle blowers warned that Boeing $737 \mathrm{NG}$ was pretty much a death trap for passengers. Boeing's $737 N G$ is flown by more than 150 airlines worldwide.

As procurement and safety officers respectively, Mr. \& Mrs. Jones discovered flaws in the production and manufacturing processes of key structural parts for many of Boeing 737NG's. Al Jazeera (2010) reported that $\mathrm{Mr}$ and Mrs Jones told the United States (US) Department of Justice in a detailed written report that the parts - made by a sub-contractor for Boeing between 1996 and 2004 - were ill-fitting and illegal, but that Boeing used many of them to build the aircraft. Aviation experts working with these whistle blowers confirmed in a television program that the problem with these parts could lead to a "catastrophic failure" of aircraft fitted with them. While Boeing dismissed these allegations as lacking merit, the American Federal Aviation Administration - which regulates the US aircraft industry - backed Boeing (Al Jazeera, 2010). Interestingly, Ducommun Technologies, an aviation services organization backed the whistle blowers. In 2005, when it became clear that there was no urgency on the part of the US Department of Justice to respond to their report, they (Mr \& Mrs Jones) went to court. To date, the US government has failed to respond seriously to the issues raised.

Keywords: Boeing, Whistle blowing, Julian Assange, Ducommum Technologies, Al Jazeera

\section{Whistle blowing}

The following elements characterise whistle blowing:

- A deliberate and voluntary act;

- Occurring in both the private and public sector;

- Act of disclosing an unethical practice or wrongdoing;

- Can result from perception or actual act of wrongdoing;

- Could cause harm to an organisation's reputation or the accused person;

- Can be carried out discretely or through an organised voluntary reporting system in an organisation;

- The whistle blower risks persecution from those he may have ratted on, thus endangering his life and the lives of his family and friends.

Essentially, whistle blowing is about making public, an organisational wrongdoing, which has the potential to cause harm to members of the public who utilise the services or products of an organisation. Wrongdoing can be described as an act that can affect an organisation's public negatively such as the use of substandard material in manufacturing, abuse of public funds, and pilfering an organisation's inventory.

There are several avenues for disclosing a wrongdoing. In some organisations, employees are encouraged to report to management, any acts of impropriety - whether actual, suspected or anticipated. In some cases, employees step beyond their organisations to an external entity, often the news media. Going 
outside the organisation to report a wrongdoing may suggest (1) a lack of confidence in the organisation to deal with the wrongdoing, and (2) the fear of victimisation.

2. Arguments for and against whistle blowing For Against

Whistle blowing is encouraged as a The whistle blower may have been part of the wrongdoing; control mechanism against fraudulent or unethical practises

Those who disclose acts of wrongdoing should be rewarded and not persecuted Whistle blowing attracts screaming headlines in news magazines and tabloids

Whistle blowing can bring about positive change in an organisation or society

\section{About Ducommum Technologies}

As a powerful player in several industries namely aerospace, defense, oil and telecommunications, Ducommum Technologies has built a reputation for designing and building illuminated keyboards, panels and pushbutton switches. They also design and manufacture severe environment motors and resolvers (AEI), electro-mechanical enclosures and cable assemblies (Mechtronics), and millimeterwave products (Wisewave Technologies). Although Ducommum Technologies has been in these industries for over 4 decades, yet it has remained a global profitable player, driving innovative solutions and services to the aerospace and high technology markets through a developed and committed workforce (Ducommum, nd).

\section{Subject area}

Corporate governance, ethics, public management, strategic human resources management

\section{Study level/applicability}

$2^{\text {nd }}$ year students up to postgraduate programmes

\section{Deliberative questions}

- Comment as to whether you believe that the whistle blowers are reacting to an internal employee dispute that seemed unfavourable to them or not.

- Do you suspect that the whistle blowers are being sponsored by Boeing's competitors who are eager to reduce Boeing's popularity in the aircraft market? Motivate your response.

- In your view, why has the US government not taken any serious action against Boeing? Suggest what sort of action they should take.

- Assume that you work for a company and discovered wrong and unethical practices, what would be your reaction? Fully motivate your response.

- Discuss the different kinds of positive and negative changes that whistle blowing may have in an organisation.

- $\quad$ The motive of the whistle blower may be questioned, leading the whistleblower to reconsider the decision to blow the whistle. Against the concept of organisational citizenship behaviour, discuss the italicised statement.

\section{References}

Al Jazeera. (2010). Boeing safety claims investigated. Accessed: 24 March 2011, <http://english.aljazeera.net/video/americas/2010/12/2010121516520679770.html>

Ducommum, (nd). http://www.ducommun.com/dti/Default.aspx. Accessed: 24 March 2011

Jubb, P. B. (1999). Whistleblowing: A restrictive definition and interpretation. Journal of Business Ethics, 21(1), 77-94. 
People \& Power: On a wing and a prayer 2010, television program, Al Jazeera, Wednesday, December 16 1900GMT.

\section{Suggested reading}

Bowen, R. M., Call, A. C., \& Rajgopal, S. (2010). Whistle-blowing: Target firm characteristics and economic consequences. The Accounting Review, 85(4), 1239-1271.

Callahan, E. S., Dworkin, T. M., Fort, T. L., \& Schipani, C. A. (2002). Integrating trends in whistle blowing and corporate governance: Promoting organizational effectiveness, societal responsibility, and employee empowerment. American Business Law Journal, 40(1), 177-215.

Dorasamy, N. (2012). Institutionalizing a whistle blowing culture within Higher Education Institutions: Policy and procedure underpinning good governance at the Durban University of Technology. Journal of Economics and Behavioral Studies, 4(9), 505-514.

Dorasamy, N. (2013). Good Governance and Whistleblowing: A Case of a Higher Education Institution (HEI) in South Africa. Journal of Social Science, 34(2), 105-114.

Dyck, A., Morse, A., \& Zingales, L. (2010). Who blows the whistle on corporate fraud? The Journal of Finance, 65(6), 2213-2253.

Institute of Directors (2002). King Report on Corporate Governance for South Africa.

\section{Acknowledgements}

The author acknowledges the critical comments of Dr Stan Cronje; Dr Rozenda Hendrickse and Ms Michelle Maree. These academics are staff of the Faculty of Business, Cape Peninsula University of Technology, South Africa. 